\title{
Membangun budaya literasi perdesaan Di Desa Pondok Kemuning Kota Langsa
}

\author{
Irfansyah ${ }^{1}$, Dedy Surya ${ }^{2}$ \\ ${ }^{1}$ Institut Agama Islam Negeri Langsa, Kota Langsa, Indonesia \\ ${ }^{2}$ Institut Agama Islam Negeri Langsa, Kota Langsa, Indonesia \\ email: dedysurya@iainlangsa.ac.id
}

$\begin{array}{ccc}\text { First received: } & \text { Revised: } & \text { Final Accepted: } \\ \text { 01 January } 2021 & \text { 02 February 2021 } & \text { 04 April } 2021\end{array}$

\begin{abstract}
Abstrak
Masyarakat Indonesia menyediakan waktu untuk membaca rata-rata hanya 3059 menit per hari, berbanding terbalik dengan negara maju yang rata-rata membaca dengan durasi mencapai 6-8 jam per hari. Tujuan pengabdian untuk menghidupkan budaya literasi di Masyarakat. Metode yang digunakan adalah penyuluhan dengan dua tahap. Pertama: tahap persiapan dengan melakukan survey, mencari tahu penyebab rendahnya literasi di masyarakat, serta menyusun program PKM terkait meningkatkan budaya literasi. Kedua: tahap pelaksanaan dengan melibatkan berbagai pihak yang dapat berpartisipasi dalam rangka menyukseskan kegiatan dan melakukan penyuluhan kepada masyarakat. Hasil pengabdian kepada masyarakat telah mampu meningkatkan kepedulian masyarakat terhadap budaya literasi terlihat dari antusias masyarakat mengikuti berbagai kegiatan yang diadakan peserta KPM . Budaya literasi perlu ditingkatkan dengan menghidupkan budaya literasi melalui penyuluhan kepada anak- anak dan pemuda desa.
\end{abstract}

Kata Kunci: budaya, literasi, desa

\section{Abstract}

Indonesian people provide time to read an average of only 30-59 minutes per day, in contrast to developed countries which read an average of up to 6-8 hours per day. The purpose of community service is to revive the literacy culture in society. The method used was counseling with two stages. First: the preparation stage by conducting a survey, finding out the causes of low literacy in the community, and compiling PKM programs related to improving literacy culture. Second: the implementation stage by involving various parties who can participate in the success of activities and provide education to the community. The results of community service have been able to increase public awareness of the literacy culture seen from the enthusiasm of the community in participating in various activities held by KPM participants. Literacy culture needs to be improved by reviving a literacy culture through outreach to village children and youth.

Keywords: culture, literacy, village 


\section{PENDAHULUAN}

Masa modern saat ini tepatnya pada masa revolusi industri 4.0 dunia teknologi memiliki perkembangan yang cukup pesat. Hal ini disebabkan dengan pesatnya perkembangan ilmu pengetahuan. Ilmu pengetahuan dapat diperoleh melalui pemanfaatan sumber informasi di sekitar masyarakat baik secara tertulis maupun tidak tertulis (Ati, dkk, 2020). Namun sedihnya perkembangan ilmu pengetahuan yang pesat memiliki dampak buruk bagi masyarakat terutama anak-anak yang diharapkan akan menjadi pemuda yang unggul dalam berbagai bidang. Data dari BPS mengungkapkan bahwa anak-anak di Indonesia menghabiskan waktu untuk menonton televisi sekitar 300 menit per harinya. Hal ini berbanding jauh dengan apa yang terjadi di negara-negara lain seperti di australia yang anak-anaknya menghabiskan waktu untuk menonton televisi 150 menit, sedangkan di amerika 100 menit dan kanada 60 menit (republika, 2015). Bahkan hasil survey dari 65 negara literasi kita menempati posisi ke 64 (Marimbun, 2020). Faktafakta lain yang dapat menyayat hati kita yaitu tingkat membaca siswa Indonesia hanya menempati 57 dari 65 negara (Republika, 2015).

Ilmu pengetahuan dapat diperoleh melalui informasi baik secara lisan maupun tulisan (Permatasari, 2015). Oleh karena itu, semakin banyak orang di suatu daerah yang memiliki pengetahuan maka semakin berkembang pula peradaban di daerah tersebut. Kemajuan teknologi yang seharusnya mampu memudahkan hidup manusia justru tidak mampu untuk meningkatkan minat literasi masyarakat. Berbagai bahan bacaan yang mudah untuk diakses seperti buku, jurnal, maupun berbagai media masa yang telah berbentuk digital yang mudah di akses oleh masyarakat tidak mampu menggugah keinginan membaca masyarakat (Dian, dkk, 2019). Kemajuan teknologi di salah gunakan oleh beberapa pihak dengan akses dengan mudah menyebarkan berita bohong atau yang dikenal dengan hoax, ujaran kebencian dan SARA, atau Suku, Agama, dan Ras Antar golongan (Ritonga \& Andhika, 2012; Miskahuddin, 2017).

Rendahnya literasi membaca juga terjadi di kota Langsa dapat dilihat secara saksama akan minimnya budaya literasi pada masyarakat maupun di kalangan pelajar, hal terbukti akan sedikitnya pengunjung di perpustakaan kota, bahkan tidak semua desa memiliki perpustakaan desa, terlebih taman baca. Hal ini bisa menjadi suatu penyebab dari minimnya sumber daya manusia. Adapun hal yang diperlukan untuk meningkatkan sumber daya manusia yaitu dengan menghidupkan budaya literasi dalam masyarakat. Salah satu untuk menghidupkan leterasi maka diperlukan adanya suatu gerakan untuk membudayakan literasi. Literasi dapat diartikan yaitu kemampuan membaca dan menulis, dalam kata lain melek aksara atau keberaksaraan. Namun seiring perkembangan zaman literasi mengalami perkembangan makna sehingga literasi ataupun keberaksaraan tidak lagi memiliki pemaknaan tunggal melainkan multi tafsir. Ada literasi komputer, literasi teknologi, literasi ekonomi, literasi informasi, literasi moral dan lain sebagainya. Literasi dapat diartikan seperti melek teknologi, melek informasi, berfikir kritis, peka terhadap lingkungan sosial hingga ke politik. Ilmu pengetahuan dapat diperoleh dengan berliterasi. Literasi menjadi suatu proses interaksi kemampuan dalam diri setiap individu dalam hal membaca, menulis, berbicara, menghitung serta memecahkan masalah. Membaca merupakan suatu proses untuk memberi arti kepada dunia. Setiap individu 
yang gemar membaca akan melahirkan generasi yang lebih baik yaitu generasi yang sebelumnya.

Terdapat beberapa faktor yang menjadi penyebab menurunnya budaya literasi di masyarakat yaitu faktor internal maupun faktor eksternal. Faktor kebiasaan mejadi faktor utama dan sangat mendasar. Hal tersebut yang terjadi di desa Pondok Kemuning, maka dari permasalahan tersebut dapat dirumuskan bagaimana cara untuk menghidupkan budaya literasi bagi masyarakat serta pemuda di desa Pondok Kemuning, Kec Langsa Lama, Kota Langsa, dengan tujuan agar dapat mengetahui cara apa saja yang dapat digunakan untuk menghidupkan budaya literasi di tempat tersebut. Adapun manfaat dari pengabdian kepada masyarakat yaitu hidupnya budaya literasi di Desa Kemuning untuk meningkatkan kualitas sumber daya manusia serta berkembangnya pengetahuan masyarakat yang disebabkan kayanya pengetahuan yang dimiliki masyarakat.

\section{METODE}

Metode yang digunakan yaitu sosialisasi dan penyuluhan. Terdapat 2 tahapan yang dilakukan dalam pelaksanaan KPM yaitu tahap persiapan dan pelaksanaan kegiatan. Tahap persiapan dapat dikatakan tahap pra pelaksanaan, maka dalam tahap ini yang dilakukan yaitu survei lokasi atau tempat pelaksanaan KPM, kemudian melakukan observasi terkait kebudayaan literasi dan bagaimana minat literasi di masyarakat serta faktor apa saja yang dapa menjadi penghambat serta yang mendorong meningkatnya budaya literasi. Tahap Pelaksanaan dengan menyusun program kegiatan setelah memperoleh hasil dari pemetaan permasalahan di atas, memberikan informasi kepada masyarakat seputar program KPM yang mahasiswa lakukan di desa Pondok Kemuning. Tahap pelaksanaan ada beberapa kegiatan mulai dengan mengajak para aktor yang berkepentingan untuk berpartisipasi dalam rangka menyukseskan kegiatan KPM. Melakukan sosialisasi kepada masyarakat serta pemuda desa serta melakukan sosialisasi kepada sekelompok pemuda yang dirasa memiliki peran yang cukup urgent dalam menggerakkan budaya literasi di desa.

\section{HASIL DAN PEMBAHASAN}

Pelaksanaan kegiatan kuliah pengabdian masyarakat ini melaui program literasi di pedesaan dilakukan di desa Pondok Kemuning, Kecamatan Langsa Lama, Kota Langsa. Kegiatan KPM ini dilakukan oleh mahasiswa Institut Agama Islam Negeri. Menggerakkan literasi di pedesaan haruslah didukung oleh berbagai pihak, yang terpenting yaitu didukung oleh pemerintah desa. Salah satu bentuk dukungan tersebut dapat berupa pemberian dukungan kepada gerakan literasi yang di selenggarakan di perdesaan yang tidak hanya ditujukan kepada kebijakan pembangunan infrastruktur literasi perdesaan tetapi juga dukungan dalam menghidupkan masyarakat untuk ikut serta berpartisipasi dalam gerakan literasi perdesaan tersebut. Maka atas dasar permasalahan tersebut, sebelum mahasiswa melaksanakan program literasi perdesaan mahasiswa mengunjungi pemerintah desa terlebih dahulu yang setelahnya barulah kelompok sasaran lainnya. Pemerintah desa menanggapinya dengan baik serta mengapresiasi adanya gerakan literasi yang di gagas oleh mahasiswa dalam program kuliah pengabdian masyarakat. 
Gerakan literasi ditujukan kepada masyarakat salah satunya dengan mengajak guru serta pengajar lembaga pengajaran Al-Qur'an yang beranggotakan ibu-ibu dari desa Pondok Kemuning sebagai penggerak dan sasaran penyuluhan gerakan literasi perdesaan. Dengan mengajak para pengajar Qur'an, maka peluang untuk membudayakan literasi semakin besar, di samping mereka memiliki akses mudah dan secara langsung dapat membudayakan literasi kepada peserta didik, hal ini diharapkan dapat menghidupkan literasi di balai-balai serta dapat menanamkan bahwa betapa pentingnya berliterasi sejak dini. Dalam proses penyuluhan, hal yang pertama yang dilakukan yaitu memberikan undangan kepada guru-guru TPA seputar acara kegiatan penyuluhan yang kami lakukan, dalam hal ini mahasiswa menyampaikan beberapa program KPM yang dilakukan serta gambaran kegiatan yang dilakukan oleh mahasiswa KPM Tanggapan yang diberikan pun sangatlah positif, para guru pengajian pun mendukung penuh atas kegiatan yang diselenggarakan mahasiswa, Para guru TPA sangat antusias berpartisipasi dalam program yang diselenggarakan tersebut dengan membawa anak-anak sebagai perwakilan dari setiap TPA yang ada di masyarakat.

Mahasiswa KPM juga melakukan penyuluhan kepada pemuda desa seperti remaja masjid setempat. Salah seorang pemuda tersebut mengatakan sebagian besar masyarakat setempat memiliki profesi sebagai petani, dari pagi hingga sore mereka berada di kebun untuk bercocok tanam, maka sangat sedikit masyarakat yang memperhatikan serta berkecimpung untuk menghidupkan budaya literasi di desa. Hal ini di anggap wajar karena berkebun merupakan pekerjaan utama yang secara otomatis harus di prioritaskan serta di dahulukan. Maka atas dasar kondisi itu tidak bisa menetapkan ekspektasi yang tinggi akan perubahan sikap masyarakat akan gerakan literasi perdesaan. Dengan adanya pelaksanaan program ini yang di pelopori oleh mahasiswa harus senantiasa berasal dari kebutuhan masyarakat, sehingga program tersebut memiliki potensi yang besar untuk berhasil, hal ini di sebabkan masyarakat di desa tersebut memiliki karakter untuk berpartisipasi dalam kegiatan yang memiliki keterkaitan langsung dengan mata pencahariannya (Herdiana, 2018). Terdapat permasalahan lain yang mahasiswa alami dalam menggerakan literasi perdesaan yaitu pandangan masyarakat yang memandang bahwa gerakan literasi seakan-akan tidak memiliki hubungan serta korelasi terhadap pekerjaan yang mereka lakoni sehari-hari, sehingga literasi oleh sebagian besar masyarakat dipandang akan tepat guna apabila diterapkan kepada anak-anak yang masih berada pada fase pendidikan sekolah serta pemuda desa, tidak tepat jika ditujukan kepada masyarakat yang sehari-harinya bekerja di kebun.

Guru pengajian Al-Qur'an merupakan tokoh yang dirasa sangatlah tepat, sehingga kegiatan tersebut sekaligus dijadikan ajang untuk memberikan penyuluhan kepada kalangan santri di TPA agar kegiatan literasi yang ada di balai pengajian tersebut digalakkan dan ditingkatkan agar menjadi sebuah gerakan yang memberikan manfaat bagi santri serta anak-anak. Kegiatan sosialisasi dan penyuluhan gerakan literasi perdesaan yang dilakukan kepada guru TPA, Guru pengajian atau TPA menyatakan dukungan dalam gerakan literasi perdesaan dan menyadari akan pentingnya literasi, Gerakan literasi perdesaan yang dilakukan dinilai tepat bagi pemuda serta anak-anak yang berada pada fase pembelajaran, sedangkan untuk masyarakat umum yang ada di 
desa kurang tepat dikarenakan mata pencaharian mereka sebagai petani tidak memiliki korelasi langsung dengan gerakan literasi perdesaan yang dilakukan di desa.
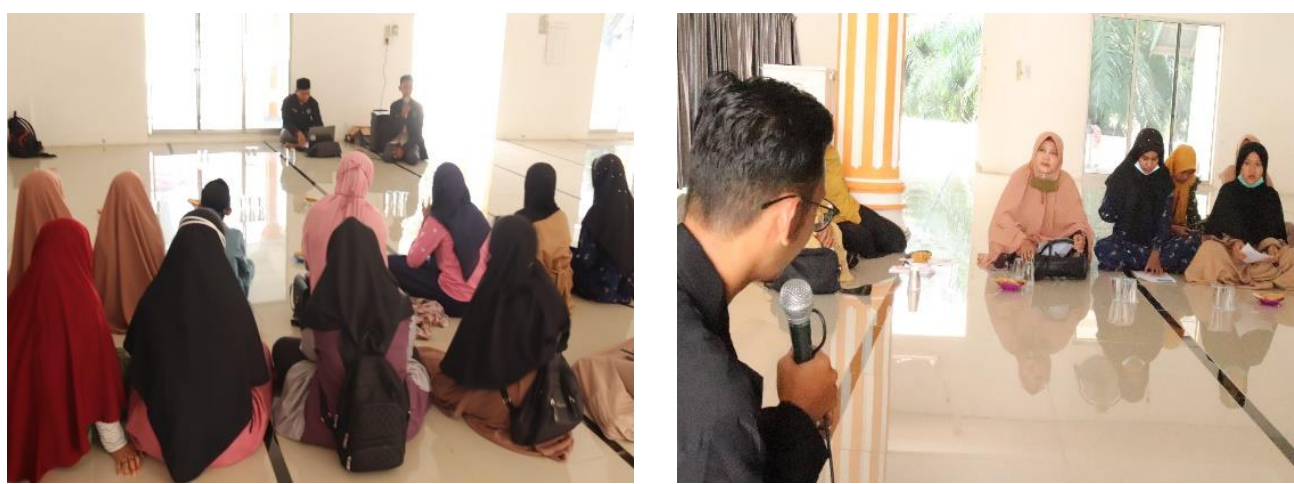

Gambar 1. Sosialisasi kepada guru TPA

Anak-anak dan pemuda merupakan sasaran yang tepat dan ideal dalam menghidupkan budaya literasi perdesaan. Hal ini dikarenakan aktivitas dalam proses belajar memerlukan berbagai referensi guna menunjang pengetahuan anak- anak dan pemuda. Adanya sikap yang menjadikan literasi sebagai sebuah kebutuhan baik untuk memperoleh pengetahuan dan budaya akan memberikan banyak manfaat bagi anak-anak dan pemuda (Irianto \& Febrianto, 2017). Perkembangan ilmu pengetahuan yang sejalan dengan teknologi informasi dapat memberikan berbagai kemudahan kepada anak-anak dan pemuda untuk mengakses literasi yang tidak hanya secara tradisional dengan mendatangi perpustakaan atau membeli buku yang menunjang proses belajar. Berbagai buku dapat dijangkau dengan menggunakan alat elektronik seperti handphone dan laptop. Bahan bacaan tersedia secara daring (online), baik yang disediakan oleh pemerintah maupun oleh organisasi swasta dan bisnis (Akbar \& Anggraeni, 2017; Silvana \& Cecep, 2018).

Beberapa fakta empiris yang mahasiswa temukan di desa Pondok Kemuning bahwa pemuda serta anak-anak tidak memaksimalkan penggunaan elektronik untuk keperluan menambah ilmu, namun mereka menggunakannya untuk game, menonton film dan lain sebagainya. Kondisi seperti ini sejalan dengan beberapa pendapat pakar seperti Lombogia, dkk (2018); Sari, dkk (2017); yang semua sependapat menyebut bahwa akses internet tidak benar-benar dimanfaatkan secara maksimal oleh pemuda serta anak-anak dan masyarakat untuk memperoleh informasi dan pengetahuan. Internet justru memberikan dampak buruk bagi anak-anak dan pemuda, salah satunya menurunkan minat untuk belajar dan memberikan sifat kecanduan terhadap hal-hal yang tidak baik. Kegiatan yang dilakukan oleh mahasiswa untuk memancing ketertarikan akan adanya literasi yaitu mengajak pemuda dan anak-anak yang ada di desa Pondok Kemuning untuk secara bersamasama berbincang seputar keilmuan dengan belajar sambil bermain. Kegiatan perbincangan dilakukan di mushalla dusun pondok indah dengan bentuk mengajak pemuda secara sukarela untuk datang. Kegiatan tersebut dilaksanakan setelah isya yang mana para remaja memiliki waktu luang untuk bersantai dan berkumpul. Hasil dari gerakan literasi terhadap anak-anak di desa Pondok Kemuning dinilai berhasil dikarenakan banyak pemuda yang secara intens mengikuti proses yang dipandu oleh 
mahasiswa sesuai dengan bidang ilmu dan keahliannya masing-masing, serta mampu meningkatkan minat pemuda setempat untuk membaca dan belajar setiap hari.
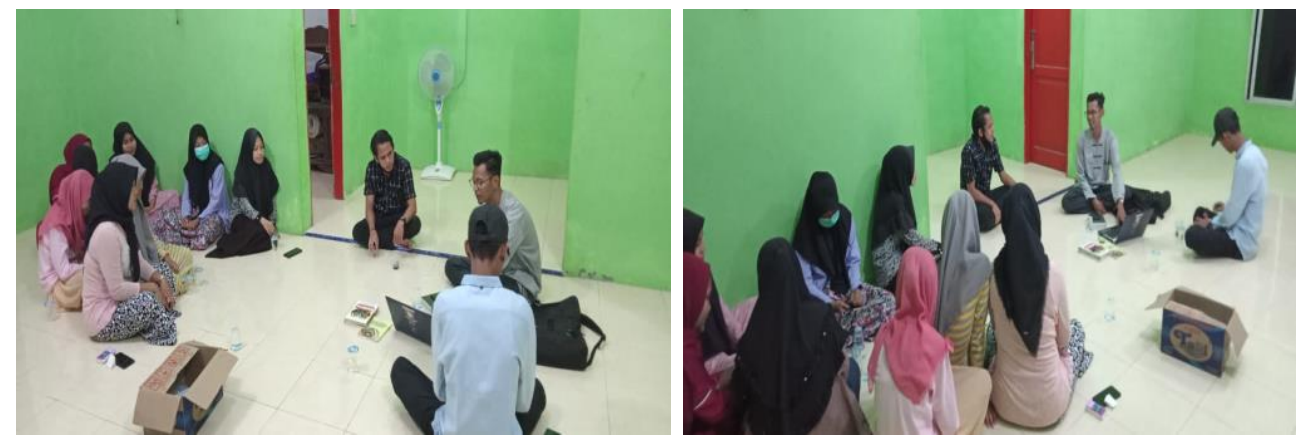

Gambar 2. Sosialisasi kepada pemuda desa

Dalam upaya menggugah kepedulian masyarakat mahasiswa yaitu memberikan reward berupa buku bacaan. Pemberian reward semata-mata untuk membangun semangat untuk menyadarkan masyarakat akan pentingnya ilmu pengetahuan yang dapat diraih dengan cara membaca, buku-buku yang menjadi reward merupakan sumbangsing langsung dari mahasiswa

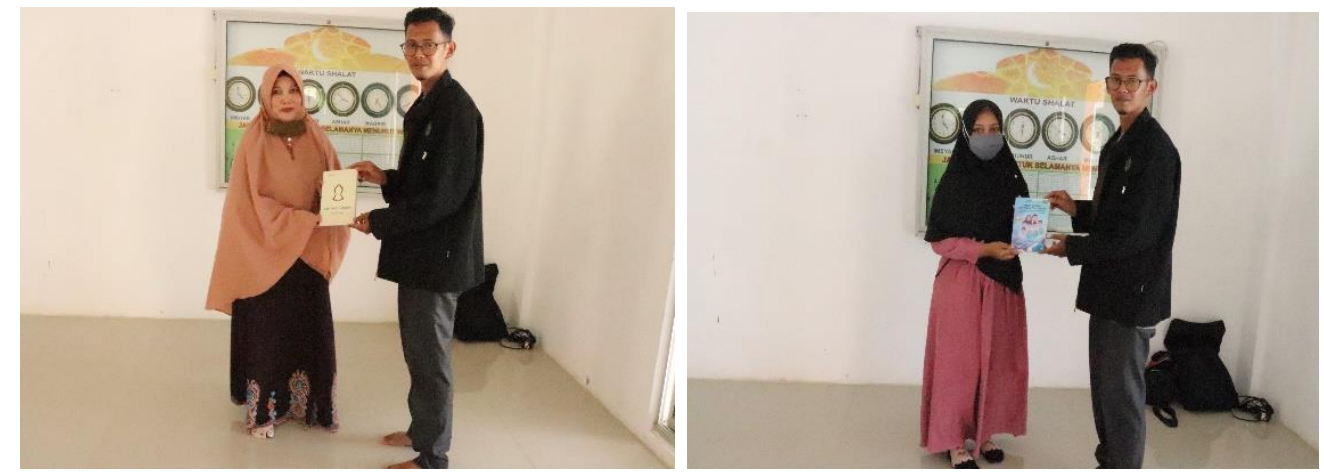

Gambar 3. Pemberian Reward dari Mahasiswa KPM

\section{KESIMPULAN}

Salah satu bentuk upaya membangun desa adalah membudayakan literasi. Gerakan literasi perdesaan yang dilaksanakan oleh Mahasiswa Institut Agama Islam Negeri Langsa (IAIN Langsa) telah memberikan hasil bagi peningkatan minat dan budaya literasi yang ada di desa Pondok Kemuning. Kegiatan yang berhasil dilaksanakan terdiri dari kegiatan penyuluhan tentang urgensi menghidupkan budaya literasi di perdesaan. Capaian kegiatan yaitu: capaian kegiatan sosialisasi pentingnya literasi perdesaan yang ditujukan kepada masyarakat desa Pondok Keuning. capaian pembelajaran literasi yang dilaksanakan untuk guru TPA, serta capaian pembelajaran dan pembimbingan literasi untuk pemuda desa. 


\section{DAFTAR PUSTAKA}

Akbar, M. F., \& Anggraeni, F. D. (2017). Teknologi dalam pendidikan: Literasi digital dan selfdirected learning pada mahasiswa skripsi. Jurnal Indigenous, 2(1), 28-38.

Herdiana, D. (2018). Dampak Pembangunan Perumahan Terhadap Perubahan Sosial Masyarakat Desa (Studi Kasus di Desa Jayamekar, Kabupaten Bandung Barat). Jurnal Pembangunan Wilayah Dan Kota, 14(4), 265-280.

Herdiana, Dian., Heriyana, Rendi., Suhaerawan, Reza. (2019). Pemberdayaan Masyarakat Melalui Gerakan Literasi Perdesaan di Desa Cimanggu Kabupaten Bandung Barat. Jurnal Pengabdian Pada Masyarakat, 4(4), 431-442.

Irianto, P. O., \& Febrianto, L. Y. (2017). Pentingnya penguasaan literasi bagi generasi muda dalam menghadapi MEA. In The 1st Education and Language International Conference Proceedings Center for International Language Development of Unissula (pp. 640-647). Semarang: Universitas Islam Sultan Agung Semarang.

Lombogia, B. J., Kairupan, B. H. ., \& Dundu, A. E. (2018). Hubungan kecanduan internet dengan kualitas tidur pada siswa SMA Kristen 1 Tomohon. Jurnal Medik Dan Rehabilitasi, 1(2), 1-8.

Marimbun, M. (2019). Minat Membaca dan Implementasinya dalam Bimbingan dan Konseling. ENLIGHTEN: Jurnal Bimbingan Konseling Islam, 2(2), 74-84.

Miskahuddin. (2017). Pengaruh Internet Terhadap Penurunan Minat Belajar Mahasiswa. Jurnal Mudarrisuna, 7(2), 293-312.

Permata sari, Ane. 2015. Membangun kualitas bangsa dengan budaya literasi. Yogyakarta : Prosiding Seminar Nasional Bulan Bahasa UNIB.

Rahmawati, Ati., Kurniawan, Iwan., Anggun, Rike Artisa. 2020. Membangun desa melalui budaya literasi. Jurnal Pengabdian Kepada Masyarakat, 1(1), 17-25.

Republika, 12 september 2015

Ritonga, S., \& Andhika, W. (2012). Pengaruh media komunikasi internet terhadap pola perilaku anak di bawah umur 17 tahun. Jurnal Perspektif, 5(2), 94-100.

Sari, A. P., Ilyas, A., \& Ifdil. (2017). Tingkat kecanduan internet pada remaja awal. JPPI (Jurnal Penelitian Pendidikan Indonesia), 3(2), 110-117.

Silvana, H., \& Cecep. (2018). Pendidikan literasi digital di kalangan usia muda di Kota Bandung. Pedagogia: Jurnal Ilmu Pendidikan, 16(2), 146-156. 